\title{
Intercropping of corn, brachiaria grass and leguminous plants: productivity, quality and composition of silages
}

\author{
Patrícia Monteiro Costa ${ }^{1}$, Severino Delmar Junqueira Villela', Fernando de Paula Leonel'2,

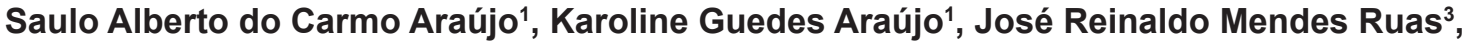 \\ Felipe Soares Coelho ${ }^{1}$, Vinícius Raimundi Andrade ${ }^{1}$
}

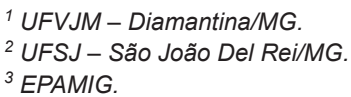

\begin{abstract}
The present study was carried out with the objective to evaluate the productive and qualitative characteristics of forages produced in systems of intercropping of corn, brachiaria grass and different leguminous plants. Productivity, bromatological composition and the fermentative profile of the silages from the following treatments were evaluated: corn in exclusive cultivation (CEC); intercropping of corn with brachiaria grass (CB); intercropping of corn, brachiaria grass and Calopogonium mucunoides (CBCal); intercropping of corn, brachiaria grass and Macrotyloma axillare (CBMac); and intercropping of corn, brachiaria grass and Stylozanthes capitata (CBSty). The experimental design utilized was completely randomized. For each type of cultivation, five plots or replications of three linear meters were harvested, and the material was separated. The variables assessed were: dry matter productivity per area; dry matter productivity of corn per area; crude protein production per area and productivity of total digestible nutrients per area. The material originated from the cultures was ensiled, with dry matter between 28 and $32 \%$. After, the material was placed and compacted appropriately in bucket silos. A sample was collected from each replication for determination of the contents of DM, crude protein (CP), ether extract (EE), lignin, neutral and acid detergent fibers (NDF and ADF) and TDN. A fraction of the sample of silages from each treatment was compressed for extraction of the juice and determination of the silage quality. There was difference between the forms of cultivation for the dry matter production per hectare. The CEC with production of $11920.1 \mathrm{~kg} \mathrm{DM} / \mathrm{ha}$ did not differ from CB (8997.41 kg DM/ha) or CBCal (10452.10 kg DM/ha); however, it was superior to CBMac (8429.75 kg DM/ha) and to CBSty (8164.83 kg DM/ha). The contents of DM, CP, NDF, ADF, lignin and TDN did not differ between the silages from the different treatments. All the silages presented good quality with good fermentation patterns.
\end{abstract}

Key Words: agriculture, cultivation system, recovery of degraded pastures

\section{Introduction}

Feeding constitutes one of the main components of cost in a cattle raising system. In tropical conditions like in Brazil, pastures are considered the most economically viable form of animal feeding. However, the pasture degradation, the scarcity of roughage feeds and the loss of nutritional values of these feedstuffs for the feeding of cattle during the dry period of the year have negatively affected the animal performance. Thus, it is necessary to recover the productivity of pastures, as well as to produce and store good-quality roughage for the period of scarcity of the year.

One of the alternatives to recover these degraded areas or areas under degradation process is the integration of agriculture with animal raising, in which one can utilize the system of intercropping. Intercropping is a cultivation system that involves the planting of two or more species in one area, so that one of the cultures can cope with the other during all its cycle, or at least part of it. Among the cultures that can be intercropped, corn and forage grasses of the genus Brachiaria have been utilized, especially when the objective is pasture recovery. The inclusion of leguminous plants in the intercropping of corn and brachiaria grass helps in the formation of a cover of residues with favorable characteristics not only to soil protection, mainly for the presence of residues of grasses, but also to the nutrition of the intercropped cultures, through the greater uptake of nitrogen promoted by these legumes (Bortolini et al., 2000).

To circumvent the problem of roughage supply in times of scarcity, there are several methods of forage conservation, among which ensilage is the most utilized. Among the forages with potential for ensilage, corn and sorghum are considered the defaults plants. However, the use of perennial grasses such as those of genera Panicum and Brachiaria in exclusive cultivation or in intercropping 
with corn, sorghum and pearl millet has been increasing (Leonel, 2007). Leguminous plants as well, both exclusively and in association with grasses, have been utilized for ensilage, mainly because of the possibility of increase in the protein content of the material ensiled.

The objective of this study was to measure the productivity of forages in function of different types of cultivation with or without intercropping of corn, brachiaria grass and leguminous plants, as well as to assess the bromatological composition and the fermentation profile of the silages produced.

\section{Material and Methods}

The experiment took place on the Experimental Farm Risoleta Neves (FERN) utilized by the consortium Universidade Federal de São João Del Rei (UFSJ)/Empresa de Pesquisa Agropecuária de Minas Gerais (EPAMIG), located in the municipality of João Del Rei, in Minas Gerais, Brazil.

The cultures were established in an area of 75,000 $\mathrm{m}^{2}$ (7.5 ha), covered with degraded pasture, in a zero-tillage system. In November 2009 and before the implantation, the plant cover was studied and the existing plants were properly chemically dissecated with herbicide with active ingredient Glyphosate. The surface liming was performed uniformly in the area with a total dose of limestone according to the results of the chemical analysis of the soil.

The seeder was regulated to obtain a population of 60 to 65 thousand corn plants per hectare. The brachiaria grass was seeded on the corn rows, and the legumes, in between. A total of $3 \mathrm{~kg} /$ ha pure, viable seeds of Brachiaria brizantha, $4 \mathrm{~kg} / \mathrm{ha}$ of Calopogonium mucunoides (calopo), $3 \mathrm{~kg} / \mathrm{ha}$ of Stylozanthes capitata, and $4 \mathrm{~kg} / \mathrm{ha}$ of Macrotyloma axilare (perennial horse gram) were utilized.

The experimental design utilized was completely randomized (experimental area with homogeneous characteristic), with 3 (three) plots or replications - each plot measured $5,000 \mathrm{~m}^{2}(0.5 \mathrm{ha})$ (5 treatments $\times 3$ replications $\times 0.5 \mathrm{ha}=7.5 \mathrm{ha})$. The total area of each treatment was of 1.5 ha with approximate dimensions of $50 \times 100 \mathrm{~m}$, with 5 rows of edging. The following types of cultivation were assessed: corn in exclusive cultivation (CEC); intercropping of corn with brachiaria grass (CB); intercropping of corn, brachiaria grass and Calopogonium mucunoides (CBCal); intercropping of corn, brachiaria grass and Macrotyloma axillare (CBMac); and intercropping of corn, brachiaria grass and Stylozanthes capitata (CBSty). The brachiaria utilized was Brachiaria brizantha (Hochst ex A. Rich.) Stapf. cv. Marandu.
For the estimation of the dry matter production of each culture, in each type of culture, five plots or replications of three linear meters were harvested at random, and the material was separated (corn plants, brachiaria grass and legumes). In each plot, the height and the number of the corn ears were also determined.

All the material was weighed, and samples were collected and sent to forced-ventilation oven at $65{ }^{\circ} \mathrm{C}$ for $72 \mathrm{~h}$, ground in Willey mill with $1 \mathrm{~mm}$ mesh sieve and conditioned for subsequent analyses.

The material was ensiled when the corn grains were at an intermediate position of the milk line, with dry matter between 28 and $32 \%$, which is the stage recommended for the obtainment of good silage. The collection of the forages of the different treatments was done with an ensiling machine attached to the power cable of a tractor, regulated for the obtainment of one and two-centimeter particles.

To evaluate the quality of the silages, the material originated from the cultures was placed and compacted at a density of $500 \mathrm{~kg} / \mathrm{m}^{3}$ in bucket silos of polyvinyl carbon (four buckets per treatment), in which silicone flanges were adapted on the lids to allow gas leakage. After filling, buckets were hermetically sealed with adhesive tapes to avoid air exchange with the environment.

After 35 days, a sample fraction of silage from each replicate was compressed for extraction of the juice, and the $\mathrm{pH}$ was subsequently determined utilizing a digital potentiometer (Digimed). The contents of lactic and butyric acids were determined by gas chromatography, according to the norms of the AOAC (1995) in the facilities of Universidade Federal de Viçosa.

The contents of dry matter (DM), crude protein (CP), ether extract (EE) and lignin (lig) of the silages were determined according to the methodology described by Silva \& Queiroz (2002) and the analyses of neutral detergent fiber (NDF) and acid detergent fiber (ADF) were done according to Van Soest (1994). These analyses were conducted in the Laboratório de Nutrição Animal of the Departamento de Zootecnia of Universidade Federal dos Vales do Jequitinhonha e Mucuri.

The total digestible nutrients (TDN) were estimated according to the equation proposed by Weiss (1992) and adopted by the NRC (2001):

$$
\mathrm{TDN}=\left[\mathrm{DCP}+(2.25 \times \mathrm{DFA})+\mathrm{DNDF}_{\mathrm{ap}}+\mathrm{DNFC}\right]-7
$$

In which: $\mathrm{DCP}=\mathrm{CP} \times \mathrm{EXP}^{[-1.2 \times(\mathrm{ADIP} / \mathrm{CP})]} ; \mathrm{DFA}=\mathrm{EE}=$ soluble matter in the treatment with petroleum ether, if $\mathrm{EE}<1 ; \mathrm{FA}=0 ; \mathrm{DNDF}_{\text {ap }}=\left[0.75 \times\left(\mathrm{NDF}_{\mathrm{ap}}-\mathrm{LIG}\right)\right] \times[1-$ $\left.\left(\mathrm{LIG} / \mathrm{NDF}_{\mathrm{ap}}\right)^{0.667}\right] ; \mathrm{DNFC}=0.98 \times\{100-[(\mathrm{NDF}-\mathrm{NDIP})+$ 
$\mathrm{CP}+\mathrm{EE}+\mathrm{ASH}]\} \times \mathrm{PAF}$, with $\mathrm{PAF}=1$. The abbreviations in the equations above represent the following items: $\mathrm{DCP}=$ digestible crude protein; $\mathrm{DFA}=$ digestible fatty acids; $\mathrm{NDF}_{\text {ap }}=$ NDF corrected for ash and protein; DNFC = digestible nonfibrous carbohydrates; EXP = exponent; FA = fatty acids; ADIP $=$ acid detergent insoluble protein; NDIP $=$ neutral detergent insoluble protein; $\mathrm{PAF}=$ processing adjustment factor; the others have been previously defined.

For the statistical analysis, software SAS (Statistical Analysis System, version 8.0) was utilized. The analysis of variance was conducted by the method of least squares (PROC GLM - Procedure General Linear Models), and when significant, the comparisons between treatments were done through the test of Student-Newman-Keuls (SNK), at a level of 0.050 of probability.

\section{Results and Discussion}

The dry matter production was altered by the types of cultivation (Table 1). The corn in exclusive cultivation (CEC) did not differ from the intercropping of corn and brachiaria grass $(\mathrm{CB})$ and the intercropping of corn, brachiaria grass and Calopogonioum mucunoides (CBCal). However, it was superior to the intercropping of corn, brachiaria grass and Macrotyloma axillare CBMac) and corn, brachiaria grass and Stylosanthes captata (CBSty). The intercropped cultivations, in turn, did not differ from each other. These results demonstrate that the participation of the leguminous plants in the total dry matter obtained by the intercropping was low, and the corn cultures did not present DM increase.

Assmann et al. (2003) studied the agriculture-livestock integration and evaluated the corn yield in cultivation with and without white clover; the authors did not verify influence from the white clover on the amount of phytomass produced. Resende et al. (2001) evaluated the sorghum-soybean intercropping and verified superiority of the intercropping in relation to the monoculture of sorghum hybrids of $42.1 \%$ total dry matter. However, Evangelista et al. (1983) evaluated the same type of intercropping and did not verify differences between the system of association and the exclusive cultivation.

The corn productivity in CEC was not different from CBCal, but it was superior to the other types of cultivation, which did not differ from each other. The competition for water and nutrients in the intercropping probably diminished the productivity of the corn intercropped; in the case of CBCal, Calopogonium mucunoides presented greater development and might have contributed with the nitrogen supply to the corn plant that developed more than in the other intercroppings.

The crude protein production in $\mathrm{kg} / \mathrm{ha}$ was low (Table 1) and no differences between the association of corn-brachiaria grass and legumes were observed, probably due to the low participation of the leguminous plants which did not add enough mass to increase the level of crude protein in the different cultivations. This result was inferior to those reported by Lempp et al. (2000), who, working with the corn-soybean association, found mean values of $678.75 \mathrm{~kg} / \mathrm{ha}$ and $512.40 \mathrm{~kg} / \mathrm{ha}$ in the first and second years of cultivation, respectively. Obeid et al. (1992b) also worked with the soybean-corn association and found values from 499.9 to $871 \mathrm{~kg} \mathrm{CP} / \mathrm{ha}$. Leonel (2007) found 806 to $822 \mathrm{CP} / \mathrm{ha}$ in the association of brachiaria grass and corn.

The quantity of TDN produced per area differed between the types of cultivation (Table 1). Corn in exclusive cultivation did not differ from intercroppings $\mathrm{CB}$ and $\mathrm{CBCal}$; the two latter did not differ from $\mathrm{CBMac}$ and CBSty. The lower values of TDN per area found in CBMac and CBSty in comparison with the other treatments are probably related to the lower production of mass in these cultivation areas. The values found in this study were inferior to those found by Leonel (2007),

Table 1 - Productivity of forages from the different types of cultivation

\begin{tabular}{|c|c|c|c|c|c|c|c|}
\hline Variable & $\mathrm{CEC}$ & $\mathrm{CB}$ & CBCal & CBMac & CBSty & P value & $\% \mathrm{CV}$ \\
\hline DMP & $11920.1 \mathrm{a}$ & $8997.41 \mathrm{ab}$ & $10452.10 \mathrm{ab}$ & $8429.75 b$ & $8164.83 b$ & 0.0332 & 17.55 \\
\hline CPP & $485.63 \mathrm{a}$ & 403.04 & 395.78 & 361.51 & 322.36 & 0.4621 & 24.8 \\
\hline TDNP & $7627.40 \mathrm{a}$ & $5387.14 \mathrm{ab}$ & $6677.80 \mathrm{ab}$ & $5565.43 b$ & $4822.07 b$ & 0.0386 & 18.62 \\
\hline \multicolumn{8}{|c|}{ Productivity } \\
\hline DMP corn & $11920.1 \mathrm{a}$ & $8526.72 b$ & $9852.91 \mathrm{ab}$ & $7953.64 b$ & $7978.41 b$ & 0.0235 & 18.60 \\
\hline DMP brachiaria & & 470.7 & 160.8 & 243.2 & 91.73 & 0.2977 & 116.34 \\
\hline DMP legumes & & & 439.2 & 233.00 & 94.8 & 0.6260 & 130.74 \\
\hline
\end{tabular}

Different types of cultivation: CEC - corn in exclusive cultivation; CB - corn and brachiaria grass; CBCal - corn, brachiaria grass and Calopogonioum mucunoides; CBMac - corn, brachiaria grass and Macrotyloma axillare; CBSty - corn, brachiaria grass and Stylosanthes capta.

CV - coefficient of variation; DMP - dry matter production per hectare; CPP - crude protein production per hectare, in kg of DM; TDNP - total digestible nutrient production per hectare, in kg of DM; DMP corn - dry matter production of corn, in kg of DM; DMP brachiaria - dry matter production of Brachiaria in kg of DM; DMP legumes - dry matter production of leguminous plants, in $\mathrm{kg}$ of DM.

Means followed by the same letters in the row do not differ by the test of Student- Newman-Keuls $(\mathrm{P}<0.050)$. 
who reported values of 8696 and $8778 \mathrm{~kg} \mathrm{TDN} / \mathrm{ha}$ in intercropping of brachiaria grass and corn in different sowing arrangements.

The height of insertion of the ear (Table 2) was not affected by the treatments. The average height of the plants in $\mathrm{CB}$ did not differ from those of the other intercroppings, but was inferior to that of corn in exclusive cultivation, which, in turn, did not differ from the other intercroppings as well.

The population density of the corn plants differed in function of the forms of cultivation; CBMac presented population inferior to $\mathrm{CBCal}$; the other treatments did not differ from each other or from the treatments mentioned above.

Martins (1994) studied the intercropping of corn with leguminous plants cultivated as green manure and evaluated the effect of the relationships between the infesting community, corn and legumes. The author verified decrease in the corn plants, in the insertion of the first ear and in the productivity of corn monocultivation kept in the grass or in the intercropping with the leguminous plants in relation to monocultivation in weeded soil.

The DM contents differed between the silages; CB presented lower values, probably due to the greater quantity of brachiaria grass, which possesses lower DM content when compared with corn. The other treatments did not differ from each other. The DM content is related to the fermentation conditions of the material and to the levels of loss in the systems; the levels considered ideal for the corn silage are between 28 and 32\% (McDonald et al., 1991).
All the silages presented DM content within the range considered adequate and close to the values found in corn silage due to its greater proportion in the ensiled mass.

The silages produced with forages from the different intercroppings and with CEC did not differ as to the CP content in the DM, probably due to the low proportion of plant mass of the legumes in relation to the total forage mass, and it was not possible to increase the crude protein content of these silages, which was close to the protein content found in corn silages.

The values found for $\mathrm{CP}$ in the present study were close to those reported by Vilela (1985), who obtained contents of 4 to $7 \%$ in the DM, although inferior to those mentioned by Evangelista et al. (1991) and Obeid et al. (1992), who obtained contents of 6.9 to 7.1 and from 5.9 to 10.9 in the $\mathrm{DM}$, respectively, for the silage of corn intercropped with soybean, and Possenti et al. (2005), who found mean values of $9.4 \% \mathrm{CP}$ in the corn silage.

There is usually greater concentration of fibers in the $\mathrm{DM}$ of grasses in relation to legumes; however, the presence of leguminous plants in the ensiled mass did not affect this variable, which was close to those found in the corn silage. The NDF contents in the DM of the silages (Table 3) varied from 475.9 to $531.7 \mathrm{~g} / \mathrm{kg}$ and were close to the values reported by Leonel (2007) (491.6 and $489.5 \mathrm{~g} / \mathrm{kg}$ ) in silages of intercropping of corn and brachiaria grass. Superior values were found by Rodrigues et al. (2004), who found mean value of $633.7 \mathrm{~g} / \mathrm{kg}$ in inoculated corn silages.

No differences were found between the ADF contents in the different treatments; the values varied from 253.9 to

Table 2 - Characteristics and population density of the corn plants from the treatments

\begin{tabular}{|c|c|c|c|c|c|c|c|}
\hline Variable & CEC & $\mathrm{CB}$ & CBCal & CBMac & CBSty & $P$ value & $\% \mathrm{CV}$ \\
\hline Height/m & $2.65 \mathrm{a}$ & $2.38 \mathrm{~b}$ & $2.56 \mathrm{ab}$ & $2.45 \mathrm{ab}$ & $2.50 \mathrm{ab}$ & 0.0346 & 4.35 \\
\hline $\mathrm{NP} / \mathrm{m}$ & $3.83 \mathrm{ab}$ & $3.16 \mathrm{ab}$ & $4.17 \mathrm{a}$ & $2.91 \mathrm{~b}$ & $3.41 \mathrm{ab}$ & 0.0262 & 14.85 \\
\hline $\mathrm{IE} / \mathrm{m}$ & 1.23 & 1.01 & 1.25 & 1.15 & 1.07 & 0.0568 & 10.35 \\
\hline
\end{tabular}

Different types of cultivation: CEC - corn in exclusive cultivation; CB - corn and brachiaria grass; CBCal - corn, brachiaria grass and Calopogonioum mucunoides; CBMac - corn, brachiaria grass and Macrotyloma axillare; CBSty - corn, brachiaria grass and Stylosanthes capta.

$\mathrm{CV}$ - coefficient of variation; Height/m - plant height, in meters; NP - number of plants per linear meter; IE - height of insertion of the ear in the corn plants.

Means followed by the same letters in the row do not differ by the test of Student- Newman-Keuls $(\mathrm{P}<0.050)$.

Table 3 - Bromatological composition of the silages from the treatments

\begin{tabular}{lccccccc}
\hline Treatment & CEC & CB & CBCal & CBMac & CBSty & P value & \%CV \\
\hline DM & $330.8 \mathrm{a}$ & $286.5 \mathrm{~b}$ & $329.9 \mathrm{a}$ & $325.5 \mathrm{a}$ & $310.4 \mathrm{a}$ & 0.0351 & 1.85 \\
CP & 52.6 & 48.5 & 49.3 & 53.7 & 51.7 & 0.0650 & 5.2 \\
NDF & 498.9 & 531.7 & 513.6 & 514.6 & 475.9 & 0.1536 & 5.9 \\
ADF & 277.5 & 285.3 & 268.2 & 259.5 & 253.9 & 0.0707 & 6.49 \\
EE & $35.6 \mathrm{~b}$ & $37.2 \mathrm{~b}$ & $39.3 \mathrm{~b}$ & $50.7 \mathrm{a}$ & $46.7 \mathrm{ab}$ & 0.0142 & 14.14 \\
Lig & 32.9 & 35.6 & 30.8 & 30.5 & 36.6 & 0.2435 & 13.51 \\
TDN & 626.1 & 604.9 & 625.2 & 648.1 & 634.1 & 0.1707 & 3.67 \\
\hline
\end{tabular}

Different types of cultivation: CEC - corn in exclusive cultivation; CB - corn and brachiaria grass; CBCal - corn, brachiaria grass and Calopogonioum mucunoides; CBMac - corn, brachiaria grass and Macrotyloma axillare; CBSty - corn, brachiaria grass and Stylosanthes capta.

$\mathrm{CV}$ - coefficient of variation; DM - dry matter; CP - crude protein ( $\mathrm{g} / \mathrm{kg}$ of DM); NDF - neutral detergent insoluble fiber (g/kg of DM); ADF - acid detergent insoluble fiber $(\mathrm{g} / \mathrm{kg}$ of DM); EE - ether extract ( $\mathrm{g} / \mathrm{kg}$ of DM); Lig - lignin $(\mathrm{g} / \mathrm{kg}$ of DM); TDN - total digestible nutrients $(\mathrm{g} / \mathrm{kg}$ of DM).

Means followed by the same letter in the row do not differ by the test of Student- Newman-Keuls $(\mathrm{P}<0.050)$. 
$285.3 \mathrm{~g} / \mathrm{kg}$ in the DM, which is close to the values found by Costa et al. (2000), who reported 267.9 to $282.2 \mathrm{~g} / \mathrm{kg}$ in the DM when working with corn silage with different proportions of ears. Possenti et al. (2005), in turn, found $319 \mathrm{~g} / \mathrm{kg}$ in the DM in corn silages, which is above the values obtained in this study.

The lignin content is associated with the indigestibility of feedstuffs; however, even more important than the lignin content is its structural arrangement on the cell wall of the forage (Jung \& Deetz, 1993). According to Mowat et al. (1969), although grasses present lower concentrations of lignin than leguminous plants, their lignin apparently inhibits the digestion more markedly, probably due to the greater concentration of hemicellulose found in the grasses. Since lignin is covalently bound to the hemicellulose, its effect would be more detrimental to the digestibility of grasses than legumes (Van Soest, 1994).

As for the contents of total digestible nutrients (TDN) (Table 3), there were no differences between the treatments, possibly because of the similarity of the silages, which possessed a greater proportion of corn in the ensiled mass. Close values were reported by Leonel (2007), who found 592.2 to $612.3 \mathrm{~g} / \mathrm{kg}$ of TDN in the DM in silages from the intercropping of brachiaria grass and corn in two sowing arrangements. Pina et al. (2006) found $628.8 \mathrm{~g} / \mathrm{kg}$ TDN in the DM in corn silage.

The $\mathrm{pH}$ of the silages showed to be adequate, not differing between the treatments (Table 4). Martin et al. (1983) and Lempp et al. (2000) found pH values of 3.85 to 4.77 and average of 3.83 , respectively, in silages of intercropping of corn and soybean.

The content of $\mathrm{N}-\mathrm{NH}_{3} / \mathrm{TN}$ is indicative of the protein degradation during the ensilage process. According to Kung Jr. \& Shaver (2001), silages of legumes of temperate climate are considered normal when they present concentrations from 10 to $15 \% \mathrm{~N}-\mathrm{NH}_{3} / \mathrm{TN}$ of the $\mathrm{DM}$ and in silages of perennial grasses, from 8 to $12 \%$. In this study, all the silages presented adequate indices, below 3.4, indicating reduced protein degradation.
The final concentration of lactic acid in the silage is indicative of the quality of the silage. Corn silages are considered of good quality when they have from 6 to $8 \%$ of lactic acid in the DM (Oliveira, 2001). None of the silages was inadequate to animal consumption, and they were within the adequate limits and considered silages of good quality (Table 4).

The contents of lactic acid found in the silages from the types of cultivation did not differ from each other, and are between 4.28 and $7.15 \%$ in the DM for lactic acid, possibly due to the great proportion of corn in the composition of these silages.

The values are close to and sometimes within the parameters considered ideal for a silage of quality. Costa et al. (2000) found values of 7.04 to $11.18 \%$ lactate in the DM of the corn silage. Martin et al. (1983) evaluated corn silages with the addition of 30,40 and $50 \%$ of soybean, and reported lactic acid values of $4.85 ; 5.00$; and $5.10 \%$ in the DM, respectively.

The butyric acid content in the silages is also an indicator of its quality, and is related to the undesirable fermentations caused by bacteria of the genus Clostridium (Mc Donald et al., 1991) and, according to Kung Jr. \& Shaver (2001), silages of leguminous plants which present adequate fermentative process posses butyric acid contents inferior to $0.5 \%$, and silages of perennial grasses, contents of 0.5 to $1.0 \%$. The levels of butyric acid found in the present study differed between the silages of CEC, CBMac and CBSty, which presented values of $0.02 ; 0.03$ and $0.04 \%$ of butyric acid. The other treatments did not differ from each other or from the abovementioned treatments. The contents were close to those found by several authors for corn silage, probably because of the great proportion of this grass in the ensiled mass. Costa et al. (2000) and Possenti et al. (2005) found average of $0.01 \%$ in the DM of corn silage, whereas Leonel (2007) found values of 0.0757 to $0.0768 \%$ working with an intercropping of brachiaria grass and corn. All the results are within the range considered adequate for these silages, which can be considered silages of good quality.

Table 4 - Quality parameters of the silages from the treatments

\begin{tabular}{llllllll}
\hline Treatment & CEC & CB & CBCal & CBMac & CBSty & P value & \%CV \\
\hline \%Lactate & 4.28 & 7.15 & 5.85 & 6.33 & 6.74 & 0.3021 & 17.39 \\
\%Butyrate & $0.02 \mathrm{~b}$ & $0.03 \mathrm{ab}$ & $0.03 \mathrm{ab}$ & $0.03 \mathrm{a}$ & $0.04 \mathrm{a}$ & 0.0469 & 14.78 \\
\% N-NH & 2.96 & 3.37 & 3.00 & 2.65 & 2.73 & 0.0891 & 12.40 \\
$\mathrm{pH}$ & 3.7 & 3.72 & 3.7 & 3.72 & 3.72 & 0.3051 & 1.04
\end{tabular}

Different types of cultivation: CEC - corn in exclusive cultivation; CB - corn and brachiaria grass; CBCal - corn, brachiaria grass and Calopogonioum mucunoides; CBMac - corn, brachiaria grass and Macrotyloma axillare; CBSty - corn, brachiaria grass and Stylosanthes capta.

Means followed by the same letter in the row do not differ by the test of Student- Newman-Keuls $(\mathrm{P}<0.050)$. 


\section{Conclusions}

The fermentative profiles of the silages accredit them as of appropriate quality. However, in function of productivity, among the leguminous plants evaluated in systems intercropped with corn and brachiaria grass, only the utilization of Calopogonium mucunoides is recommended.

\section{References}

ASSOCIATION OF OFFICIAL ANALYTICAL CHEMISTS AOAC. Official methods of analysis. 16.ed. Washington, D.C.: AOAC, 1995. 1094p.

ASSMANN, T.S.; RONZELLI JÚNIOR, P.; MORAES, A. et al. Rendimento de milho em área de integração lavoura-pecuária sob o sistema plantio direto, em presença e ausência de trevo branco, pastejo e nitrogênio. Revista Brasileira de Ciência do Solo, v.27, p.675-683, 2003

BORTOLINI, C.G.; SILVA, P.F.R.; ARGENTA, G. Sistemas consorciados de aveia preta e ervilhaca comum como cobertura de solo e seus efeitos na cultura do milho e sucessão. Revista Brasileira de Ciência do Solo, v.24, p.897-903, 2000.

COSTA, C.; CRESTE, C.R.; ARRIGONI, M.D.B. et al. Potencial para ensilagem, composição química e qualidade da silagem de milho com diferentes proporções de espigas. Acta Scientiarum, v.22, n.3, p.835-841, 2000.

EVANGELISTA, A.R.; GARCIA, R.; GALVÃO, J.D. et al. Efeito da Associação milho soja no valor nutritivo na silagem. Revista da Sociedade Brasileira de Zootecnia, v.12, n.1, p.50-59, 1983.

EVANGELISTA, A.R.; GARGIA, R.; OBEID, J.A. et al. Consórcio milho-soja: rendimento forrageiro e valor nutritivo das silagens. Revista Brasileira de Zootecnia, v.20, n.6, p.573-577, 1991.

JUNG, H.G.; DEETZ, D.A. Cell wall lignification and degradability. In: JUNG, H.G.; BUXTON, D.R.; HATFIELD, R.D. et al. (Eds.) Forage cell wall structure and digestibility. Madison: ASA/ CSSA/SSSA, 1993. p.315-346.

KUNG JR., L.; SHAVER, R. [2001]. Interpretation and use of silage fermentation analysis reports. Focus on Forage, v.3, n.13, 2001. Available at: <http://www.uwex.edu/ces/crops/uwforage/ Fermentation.pdf $>$ Accessed on: Mar. 12, 2011.

LEMPP, B.; MORAIS, M.G.; SOUZA, L.C.F. Produção de milho em cultivo exclusivo ou consorciado com soja e qualidade de suas silagens. Arquivo Brasileiro de Medicina Veterinária e Zootecnia, v.52, n.3 p.243-249, 2000.

LEONEL, F.P. Consórcio capim-braquiária com milho ou soja: produção e composição químico-bromatológica das silagens. 2007. 149f. Tese (Doutorado em Zootecnia) - Universidade Federal de Viçosa, Viçosa, MG.
MARTINS, D. Comunidade infestante no consórcio de milho com leguminosas. Planta Daninha, v.12, n.2, p.100-105, 1994.

MARTIN, T.L.C.; GARCIA, R.; SILVA, J.F. Efeito da associação milho-soja (Glycine Max) na qualidade da silagem. Revista da Sociedade Brasileira e Zootecnia, v.12, n.3, p.562- 575, 1983.

McDONALD, P.; HENDERSON, A.R.; HERON, S.J.E. The biochemistry of silage. Marlow, Buckinghamshire, UK: Chalcombe Publications, 1991. 109p.

MOWAT, D.N.; KWAIN, M.L.; WINCH, J.E. Lignification and in vitro cell wall digestibility of plant parts. Canadian Journal of Plant Science, v.49, p.499-504, 1969.

NATIONAL RESEARCH COUNCIL - NRC. Nutrient requirements of beef cattle. 7.ed. Washington, D.C.: National Academy Press, 2001. 381p.

OBEID, J.A.; GOMIDE, J.A.; CRUZ, M.E. et al. Silagem consorciada de milho (Zea mays, L.) com leguminosas: produção e composição bromatológica. Revista da Sociedade Brasileira de Zootecnia, v.21, n.1, p.33-38, 1992a.

OBEID, J.A.; GOMIDE, J.A.; CRUZ, M.E. Qualidade e valor nutritivo de silagem consorciada de mlho (Zea mays) com soja anual (Glycine $\max$ (L.) Merril). Revista da Sociedade Brasileira de Zootecnia, v.21, n.1, p.39-44, 1992 b.

OLIVEIRA, J.S. Manejo do silo e utilização da silagem de milho e sorgo. In: CRUZ, C.C.; PEREIRA FILHO, I.A.; RODRIGUES, J.A.S. et al. (Eds.) Produção e utilização de silagem de milho e sorgo. Sete Lagoas: Embrapa Milho e Sorgo, 2001. p.473-518.

PINA, D.S.; VALADARES FILHO, S.C.; DETMANN, E. et al. Efeitos de indicadores e dias de coleta na digestibilidade dos nutrientes e nas estimativas do valor energético de alimentos para vacas alimentadas com diferentes fontes de proteína. Revista Brasileira de Zootecnia, v.35, n.6, p.2461-2468, 2006.

POSSENTI, R.A.; FERRARI JUNIOR, E.; BUENO, M.S. et al. Parâmetros bromatológicos e fermentativos das silagens de milho e girassol. Ciência Rural, v.35, n.5, p.1185-1189, 2005.

RESENDE, P.M.; SILVA, A .G.; CORTE, E. et al. Consórcio sorgosoja. v. Comportamento de híbridos de sorgo e cultivares de soja consorciados na entrelinha no rendimento de forragem. Ciência Rural, v.31, n.3, p.369-374, 2001

RODRIGUES, P.H.M.; RUZANTE, J.M.; SENATORE, A.L. et al. Avaliação do uso de inoculantes microbianos sobre a qualidade fermentativa e nutricional da silagem de milho. Revista Brasileira de Zootecnia, v.33, n.23, p.538-545, 2004.

SILVA, D.J.; QUEIROZ, A.C. Análise de alimentos (métodos químicos e biológicos). 3.ed. Viçosa, MG: Editora UFV, 2002. 235p.

VAN SOEST, P.J. Nutritional ecology of the ruminant. 2.ed. Ithaca: Cornell University Press, 1994. 476p.

VILELA, D. Sistema de conservação de forragem, 1) silagem. Coronel Pacheco: EMBRAPA-CNPGL, 1985. 15p. (Boletim de Pesquisa, 11).

WEISS, W.P.; CONRAD H. R.; PIERRE, N. R. A theoretically-based model for predicting total digestible nutrient values of forages and concentrates. Animal Feed Science and Technology, v.39, p.95-110, 1992. 